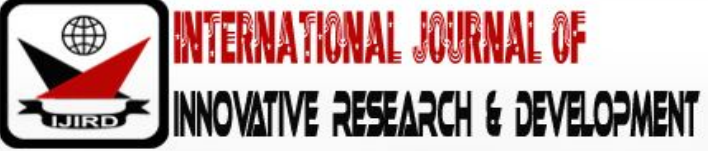

ISSN 2278 - 0211 (Online)

\section{Factors that Affect Location Choice of Hotel Property in Bauchi Metropolis, Nigeria}

\author{
Hamisu Abdulkadir Noma \\ Lecturer, Department of Estate Management, Federal Polytechnic, Bauchi, Nigeria \\ Hafsatu Jidere Bala \\ Instructor, Department of Estate Management, Federal Polytechnic, Bauchi, Nigeria
}

\begin{abstract}
:
In every industry, competition is a moving factor which silently plays for success. Also, for hotels, each brand competes with the other to occupy the best of locations which can attract customers and boom their business. This work attempts to determine the factors that are responsible for selecting a site for hotel properties in Bauchi Metropolis. Both qualitative and quantitative approach was used in this work; the qualitative approach involved conducting interview with proprietors/ owners of different hotel businesses in Bauchi metropolis. This was done to collect information from people that have the on-field experience on the subject of the research. The quantitative approach takes a survey on hotel managers and Estate Surveyors and Valuers in the study area. The reason for conducting both approaches for the research was to reduce the chances of biased opinions that could have been received as a matter of a specific type of sample group. By asking the proprietors/ owner and customers, as well as the managers and Estate Surveyors and Valuers in the study area made it possible to get a holistic perspective on the situation. Use was made of ranking in order of importance (RII) scale to analyse the factors responsible for the selection of site for hotel property in the study area. For the ranking, there were six different headings of selection factors: general location, position of site, demographics, traffics information, competition, and cost consideration. Factors to be ranked were listed under each heading; the factors were adopted from (Mahmutogullari \& Kara, 2016). The findings revealed that, general location, position of site, competition, and cost consideration were ranked high. This study identified 56 factors that affect the site selection of hotel property in the study area. Property developers should examine all of these factors, that is, who plan to develop newly or expand but have little experience with the real estate development.
\end{abstract}

Keywords: Hotel property, location choice, determinants

\section{Introduction}

The hotel industry consists of restaurants, bars, and other away-from-home eating facilities. A variety of areas cans serve as lucrative for the industry, from free-standing stalls, to take-away counters, to forming a counter in or surrounding the premises of another business, like a garment mall or gas station. (Yang, Tang, Luo, \& Law, 2015). It may be leased space, a building for store procurements or a new building constructed to design, each has its own advantages and disadvantages for exact types of hotels(Rajkumar, 2013). Freestanding hotels are often more highly priced than smaller outlets or drive-through chains (Hou, 2016). Hotel business investors have to cultivate their minds hard and deep to decide on the most valuable location for their project (Freeman \& Styles, 2014). Today, there are hardly any other factor more important than location, for consideration of the investors (Belkhodja, 2016). Location has become a primordial factor for successful business. For hotels, food quality, concept, environment do play roles in facilitating the business, however, if the locality is not popularly known, cannot be easily accessed with generic conveyance, or just do not have much population, the hotel cannot make it to the imagined heights (Karakitsiou, 2015). Owners of hotel want the best location for their project and hence site selection can be a pretty tormenting work for a successful hotel; it can take months or years of research in getting an accurate site (Ansar, 2013).

Getting a right location calls for enough time dedication and prominent hard work which comes with some predetermined factors; the factors usually combines facts with good judgment (Shao \& Shang, 2016). Location objectives can be multifarious like having a potential for adequate sales, i.e. more profit, or eradicating the cost of building a shop, or reducing the gains of prospective competitors, and improving the prospects of gaining more customers from a neighboring business. You can acquire real estate by purchase or lease. Whether, it is leased or purchased, site selection is critical to the success of a business.

Due to the rising costs of land, building and construction, and associated interest rates, the significance of avoiding poor or mediocre locations has heightened (Mesquita, 2016). Hotel site selection is increasingly complicated business these days. Demographic studies, focus groups, consumer surveys, consultants, and endless number crunching 
are all part of the formula. No hotel single shingle, multi-concept operator or large chain can afford to open an eatery today without spending time and money on some or all of the above (X. He \& Wei, 2013). However, limited information is available on the relative importance of various site selection factors (G. Li, Chen, Feng, Tan, \& Li, 2014).Site selection has to be done carefully, because the success or failure of a hotel depends largely on its location. A careful assessment of hotel sites by an experienced professional is necessary and the above assertion is supported by ( Ishikawa, 2015; Dubé, Brunelle,\& Legros, 2016; Pick, Turetken, Deokar, \& Sarkar, 2017). The business company also has its pooled experience to guide it. Given the importance of location to most hospitality operations, the availability of expert advice is important (Ongore \& Kusa, 2013; Guzman, 2015).

There is no question that proper site selection is critical in most ventures providing a consumer service or product (Eckert, He, \& West, 2015). In the extremely competitive retail environment, even slight differences in location can have a significant impact on the market share and profitability. Most importantly, since store location is a long-term fixed investment, the disadvantages of a poor location are difficult to overcome (ELSamen \& Hiyasat, 2017). Basic to the success or failure of any retail firm are decisions about location. An outlet can have quality offerings, excellent personnel, and competitive prices but fail because it is not conveniently located. Store location has a major influence on a store's success (Dong, 2013; Z. He, Cheng, Dong, \& Wang, 2016).

As cities like Bauchi grows and becomes urbanized also, the industry grows and matures, and as competition continues to intensify, competition for prime sites also intensifies. Property investors are forced to find better and more innovative methods of locating and evaluating sites. A key challenge facing every investor today is how to quickly identify the factors that determine a successful business location (Melanda, Hunter, \& Barry, 2016; North \& Miller, 2017;ELSamen \& Hiyasat, 2017). The location greatly affects the success of hotels. However, limited information is available, even though the importance of site selection has been highly recognized. The problem for this study is to identify the site selection factors that influence the hotel property industry in the study area.

Site selection is important because, whether leased or purchased, the success or failure of a hotel property depends on its location. Companies devote significant time and resources to analyzing each prospective site. However, limited information is available on the relative importance of various site selection factors for hotel property. Established businesses have expert in real estate and property development staff and provide their assistance to developers. The developers select the site for the business or evaluate the site proposed by the investor with the established site selection criteria. The objective of this study is to identify and rank the importance of the site selection factors that influence the hotel industry in the study area.

\section{Literature Review}

\subsection{Concept of Hotel Property}

A Hotel is a commercial establishment that provides lodging, food, and other services to the public. The hotel business is an important industry in many countries, especially in those attracting a large tourist trade. Hotels can be classified according to location, facilities and services offered, and clientele served (Nzilani, 2014). The commercialization of hotels is recent developments in the last few centuries attributed to U.S. Hotels were always located based on transportation availability. During colonial times hotels were usually situated at seaport towns, but by the end of the 18th century, with the rush of stagecoaches in the United States, many ordinary accommodations like inns were offered along highway routes. After the construction of railroads in the 19th century, larger hotels were built near railroad stations to accommodate railway travelers. Service standards were improved drastically to achieve maximum customer satisfaction and there came the concept of luxury hotels.

The old Waldorf-Astoria Hotel in New York City and the Brown Palace in Denver, Colorado, were among the first such luxury hotels, but their rates were too high for the average travelers. Shortly before World War I, grand hotels with elaborate services but fitting the middle-class pockets were constructed. The first such institution was the Sattler Hotel in Buffalo, New York, which opened in 1908. For years it served as a model for other large-city transient hotels. The general prosperity following World War I made travel accessible for most commoners. Business travels and reservations down the time, urged owners to construct hotels in business specific areas of the city, and paralleled emerged the concept of motels which provided cheap basic accommodation with no luxuries. In the 1920s, professional schools of hotel management were created to prepare Americans for positions in the industry. Technical schools were also founded to train skilled employees such as chefs. Today many colleges and universities offer a degree in hotel administration, and trade schools provide courses in both hotel and restaurant work. European-trained personnel are also welcome to contribute their skills in the U.S. hotel industry. Corporate ownership of hotel became a growing trend in the 1920s, which trod over individual ownership, due to the exhilarating costs of building and maintenance of hotels. Chain operation in the hotel and motel industry is a continuing trend in the U.S. and abroad. It allows for efficient management using mass purchasing, central reservations and billings, and extensive advertising and promotion campaigns. Today about 30 percent of all-American hotels and motels are affiliated with chains or franchised groups

During World War II the hotel business flourished. No new hotels were built, but existing establishments were occupied nearly to capacity at all times. Because of the growing importance of automobile travel soon after World War II, almost all the new hotels built then were located near highways. In the late 1950s motels began to combat hotels with their wider range of services, equivalent to that of hotels, but at a moderate price. Motels have increased greatly in number during the last 30 years, and the number of hotels has decreased somewhat. Today the motor hotel, offering the convenience of the motel and the service of the hotel, is becoming popular. More efficient transportation and the growing importance of air travel have reduced the need for accommodations along highways. Motor hotels are now being built 
within the boundaries of large cities and near airports. To deal with stiffer competition, a growing trend has been for hotels and motels to offer greater conveniences, such as faxing and photocopying for business travelers. Low hotel occupancy rates in the 1970s led to the development of budget motels, with cheaper lodging and fewer amenities. Country inns and bed-and-breakfasts have also grown in popularity since the 1970s; often located in rural areas, they offer a homey atmosphere and personal service.

\subsection{Types of Hotel Properties}

According to (Corgel and White ( 2015), a Washington based hotel consultant, there are many different kinds of hotels, and three major ones are, hotels for travelers, commercial and resort. The transient hotel is usually located within city boundaries and caters to people travelling for business or pleasure. Motor hotels or motels cater to the same group of persons, but are often situated near or along major highways. Both hotels and motels provide numerous amenities in addition to sleeping accommodations, including maid service, radio, and television, parking space for automobiles, recreational facilities, food and beverage services, and retail shops. This hotel they provide only food and lodging but, many large resort hotels could not stay in business except they provide sport and entertainment facilities. Hence, some of the major resort hotels provide swimming pool, golf centre, tennis court, boating dancing and horseback riding and planned social activities and entertainment. The residential hotel caters to permanent residents rather than to travelers. These hotels are similar to apartment buildings except that they provide maid and valet service, and often have dining facilities. Lodgings are available on a weekly, monthly, or yearly basis.

\subsection{Location and Hotel Property}

A location of any development involves both the analysis of the location and the site selection, in other words, identifying the general area for the business and identifying a specific site within the area (Cliquet, 2013;Ali, El-barmelgy, Shalaby, Nassar, \& Ali, 2014; Y. M. Li, Chou, \& Lin, 2014; Mulley, Ma, Clifton, Yen, \& Burke, 2016). Location refers to a general area within a city, while the site is a specific piece of property ( $\mathrm{Lv} \&$ Spigarelli, 2016). A common approach to site evaluation is to first develop a checklist to ensure that all relevant factors are considered. Essentially, it involves an evaluation of various factors that are likely to impact upon sales and costs at a site; judgment about the desirability of the site is

\subsection{Location and Hotel Property}

A location of any development involves both the analysis of the location and the site selection, in other words, identifying the general area for the business and identifying a specific site within the area (Cliquet, 2013;Ali, El-barmelgy, Shalaby, Nassar, \& Ali, 2014; Y. M. Li, Chou, \& Lin, 2014; Mulley, Ma, Clifton, Yen, \& Burke, 2016). Location refers to a general area within a city, while the site is a specific piece of property (Lv \& Spigarelli, 2016). A common approach to site evaluation is to first develop a checklist to ensure that all relevant factors are considered. Essentially, it involves an evaluation of various factors that are likely to impact upon sales and costs at a site; judgment about the desirability of the site is made based on this evaluation (Alañón-Pardo \& Arauzo-Carod, 2013; Dubé et al., 2016; Elgar, Farooq, \& Miller, 2015). Several standard checklists have been published to aid the evaluation process. These worksheets commonly include information on the socioeconomic and demographic composition of the neighborhood, level of competition, and existing retail outlets in the area(Tate, Ellram, Schoenherr, \& Petersen, 2014; Verhetsel et al., 2015; van den Heuvel, van Donselaar, de Langen, \& Fransoo, 2016). Site-specific factors such as traffic count, parking facilities, ease of ingress and egress, and visibility are also considered ( Newing,Ozuduru \& Guldmann, 2013 Clarke, \& Clarke, 2014; Xu, Zhang, \& Aditjandra, 2016; Mulley \& Tsai, 2016;). While some of the data may be quite subjective, the use of worksheets allows consistency of the data-collection process and some judgment of information on different possible positions.

It is stated that the value of a location depends upon four factors: (1) Its accessibility to the neighborhood population; (2) Its accessibility to people moving about or coming together on errands other than shopping; (3) Its physical desirability from the standpoint of grade or level, appearance, size, shape, neighborhood or district environment, and other amenities and (4) its reputation (Giner, Santa-María, \& Fuster, 2017). Location analysis should begin with a general area analysis including economic conditions, population, potential competition, and growth. It also requires the definition of a trading area, roadway and transportation system, and traffic patterns and the volume of traffic (Yang et al., 2015). Yang, Luo, and Law(2014) highlighted the major topics that must be addressed in a location strategy as follows: (1) Internal factors (company): type of retail business, type of markets, sales expectations, market coverage requirements, operating policies, merchandising approaches, pricing, and advertising (2) External factors ( market): physical environment, economic base, population base, demographic characteristics, expenditure potential, retail environment, and available existing facilities

The location decision is important because opening a business costs a lot of money, the retailer is committed to the location for a long period of time even with a lease, competition is getting tougher and a good location is one way to beat the competition, and problems such as store saturation, an uncertain economy, and tough zoning laws are making good locations harder to find. Simply estimating probable sales is not enough in a location decision, the types of customers who are candidates for the merchandise sold by the firm, the prospects for future growth in the trading area, customer lifestyles, and probable future competition should be considered (Russell, 2013; Yang et al., 2014, 2015 Corgel et al., 2015;).

Whatever the occasion or motive for locating a restaurant, there are eight principles which must be observed in applying selection criteria to each specific site as follows: adequacy of present trading area potential, accessibility of site to trading area, growth potential, business interception, cumulative attraction, compatibility, minimizing of competitive 
hazard, and site economic. Specific site selection involves the study of a trading area, traffic, complementary and competing outlets, and vulnerability, parking surroundings, area changes, and cost. It also considers ease of entrance and exit from the site, the site's visibility, nearby land use, the size of the site, and its cost (Yang et al., 2015). Evaluating a specific site is important. Choosing a specific site involves assessing the adequacy and potential of vehicular or passenger traffic passing a site, the ability of the site to intercept traffic en route from one place to another, the nature of adjacent stores, type of goods sold, and adequacy of parking (Yang et al., 2014). Corgel et al(2015) identified several criteria applicable to competent site selection, depending on the location's ability to capitalize on the franchise trademark.

Those criteria are demographics, accessibility, and market range, residential vs. commercial mix, visibility signage, longevity, direct and indirect competition, and tenant combinations. Factors to be considered in site analysis are zoning, area characteristics, physical characteristics, cost consideration, utilities, access, position of site, traffic information, availability of services, visibility, competition, market, and type of restaurant and service ( Kimelberg \& Williams, 2013; Quintos, 2013; Robinson \& Stocken, 2013Guzman, 2015). Access, visibility, traffic counts, centre size, and the presence of other complementary stores including restaurants have been addressed as the factors that affect restaurant placement in empirical studies (Russell, 2013; Yang et al., 2015;Corgel et al., 2015;). Access generally refers to the convenience of local transportation and parking. Several empirical studies have linked access to the location needs of convenience retail stores and restaurants (B. Lee, 2013; Aw \& Lee, 2014; G. Li et al., 2014). Visibility concerns the ability of potential shoppers to enjoy an unobstructed view of a store or its sign from a number of vantage points. The importance of this factor has been demonstrated with respect to supermarket location and shopping centre vacancy rates (Yang et al., 2015).

The factor of a store or the nearest public roadway is also an important consideration for restaurant location, shopping centre size, the additional amount and type of no restaurant retail space, and the anchor tenants for the centre are also important considerations (Alañón-Pardo \& Arauzo-Carod, 2013;Zhao, Lasternas, Lam,Yun, \& Loftness, 2014; Elgar et al., 2015; Giner et al., 2017). The presence of other fast-food restaurants or food stores may help rather than hinder a sale, which indicates that shoppers may be attracted to an area rather than to a specific store. The presence of other restaurants in the immediate vicinity is often referred to as a restaurant cluster. The other factors in many studies include demographic factors such as population, the number of households, income and per capita income and macro location factors such as whether a store is located in a college town or in a suburban location (Mahmutogullari \& Kara, 2016).This chapter reviewed the literature related to the areas of hotel, location, site analysis, and site selection factors. The review of hotel covered the definition, history, types of foodservices hotels. The review on site selection involved location analysis and site analysis and is used as foundation to group the factors. The factors considered in the literature were also reviewed.

\section{The Research Framework Development}

The development of framework is either from the summary of the issues from the literature or existing models.

In this study, the development of the framework is from both the existing models and review of the existing literature. The figure below represents the framework upon which the study is going to be based. The model identified the location choice to consist of two analyses that is, site selection analysis and general area analysis and the factors that affect them which influence the value of hotel properties. The factors are divided into 6 headings: general location, position of site, demographics, traffic information, competition, and cost consideration.

General Location refers to a general area within a city. The factors related to the general location include but are not limited to population (density), market statistics, and neighborhood. Position of Site is a specific piece of property. Size, parking facilities, accessibility of utility and public services, convenience, and visibility are factors related to but not limited to the position of site Demographics Information pertaining to consumers must be collected including data about age, sex, occupation, income, food preferences and potential for future growth and development. Traffic Information Traffic flow patterns are important for the analysis of the site. The factors related to traffic information include traffic counts and patterns, and frequency pattern of traffic flow. Competition A restaurant operation must consider its actual and potential competition. The factors related to competition include but are not limited to location and operating results of competitor, and proximity to competitor. Cost Consideration Costs associated with the development of the site need to be calculated carefully. This includes both the cost of purchase and the cost of site development, which covers factors such as building, landscaping, and the provision of associated facilities such as car parking and access roads. The cost of improvement - renovations and modifications - is also important to be considered (Kimelberg \& Williams, 2013). 


\subsection{Conceptual Framework}

Based on the research question, this study will use this research framework:

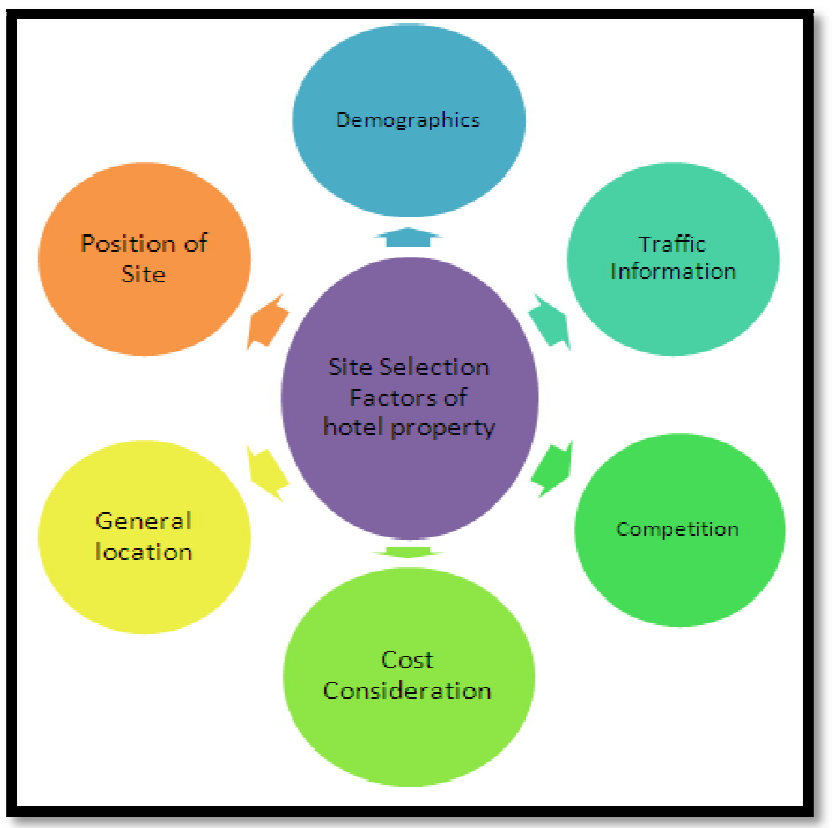

Figure 1: Conceptual Framework

Source: Field Survey (2017)

\section{Methodology}

\subsection{Instruments Used for Data Collection}

This research utilized both quantitative and qualitative research methods. The instrument used to collect data was survey questionnaire, interview, and observation. A set of questionnaires containing 56 questions divided into 8 sections were developed based on a question used previously by another author (Johnson \& Onwuegbuzie, 2004). Different question-type, such as ranking order of importance was used in the question. The different sections of the questionnaire were: demographic information, factors that affect: general location area, position of site, demographic, traffic information, competition, cost consideration and comments. The question was piloted to a group of experts to assess its validity before it was distributed.

The qualitative data for the research came from interview and observation. The interview was utilized to confirm the findings from the questionnaire as well as to triangulate the data collection methods. Three respondents were involved in the interview. Six questions were prepared after consultation with several experts in the topic area. The interview further explored the phenomenon of the factors that influence the location choice of hotel property in the study area Observation was another method of data collection for the research. In this study, observation was used for obtaining the factors that determine the site selection for hotel property among selected respondents.

\subsection{Respondents of the Study}

The respondents of the study were hotel managers and practicing Estate Surveyors and Valuers in the study area. A total of 30 questionnaires were distributed to hotel managers and practicing Estate Surveyors and Valuers in the study area. 30 were returned. Of these 20 were male while the rest (10) were female.

\subsection{Research Procedure}

Before the actual data collection, a pilot study was conducted to assess the validity of the research instrument. 10hotel property experts were involved in the pilot study chosen at random at various locations in the study area. During the actual study, the questionnaires were distributed at various locations in the study area.

\subsection{Methods of Data Analysis}

To analyze the data, six variables were taken into consideration namely, general area location, position of site, traffic information, demographics, completion and cost consideration. The data were ranked according order of importance. Results were presented through frequency counts and descriptive statistics and the interview data was transcribed. 


\section{Findings and Discussion}

\subsection{Preliminary Survey}

Data were collected through the distribution of (30) questionnaires to hotel managers and practicing Estate Surveyors and Valuers in the study area and the 30 questionnaires were returned.

\subsection{Analysis of Questionnaire}

The questions that were instrumental in reaching acceptable deductions were evaluated as well as tables in summarizing the data from field survey in relation to the factors that affect location choice of hotel property.

\subsubsection{Analysis of Questionnaires Administered}

The level of response for the total number of questionnaires administered is presented below.

\begin{tabular}{|c|c|c|c|}
\hline S/ N & Respondents & Frequency & Percentage (\%) \\
\hline 1 & NO returned & 23 & 76.67 \\
\hline 2 & NOT returned & 7 & 23.33 \\
\hline 3 & Total & 30 & 100 \\
\hline
\end{tabular}

Table 1: Number of Questionnaires Administered

Source: Field Survey, 2016

Thirty (30) questionnaires were distributed to respondents and the thirty (23) were returned, $76.67 \%$.

\subsubsection{Demographic Information}

It has been observed that male responded than the female within the study area.

\begin{tabular}{|c|c|c|c|}
\hline S/ N & Gender & Frequency & Percentage (\%) \\
\hline 1 & Male & 15 & 65.22 \\
\hline 2 & Female & 8 & 34.78 \\
\hline & Total & 23 & 100 \\
\hline
\end{tabular}

Table 2: Gender of the Respondents

Source: Field Survey, 2016

It can be seen from the table above that twenty (15) respondents, representing $65.22 \%$ of the respondents are male, while ten (8) respondents representing $34.78 \%$ are female. The analysis was carried out to that the research work is gender sensitive.

\subsubsection{Marital Status of the Respondents}

\begin{tabular}{|c|c|c|c|}
\hline S/ N & Marital Status & Frequency & Percentage (\%) \\
\hline 1 & Married & 15 & 65.22 \\
\hline 2 & Single & 6 & 26.09 \\
\hline 3 & Widow & 2 & 8.69 \\
\hline & Total & 23 & 100 \\
\hline
\end{tabular}

Table 3: Respondent Marital Status

Source: Field Survey, 2016

\subsubsection{Occupational Status of the Respondents}

\begin{tabular}{|c|c|c|c|}
\hline S/ N & Occupation & Frequency & Percentage (\%) \\
\hline 1 & Employed & 14 & 60.87 \\
\hline 2 & Self Employed & 9 & 38.13 \\
\hline & Total & 23 & 100 \\
\hline
\end{tabular}

Table 4: Occupation of the Respondents

Source: Field Survey, 2016

The table above shows that twenty (14) respondents representing $60.87 \%$ of the respondents are employed and ten (9), 38.13\% are self-employed 


\begin{tabular}{|c|c|c|c|c|c|}
\hline Factors & Mean & Median & STD.DEV & CV\% & Rank \\
\hline Concentration of target of Customers & 3.70 & 6.0 & 0.74 & 3.90 & 2 \\
\hline $\begin{array}{c}\text { Sales generators (i.e., retail, } \\
\text { Employment, market efficiency, average sales etc) }\end{array}$ & 3.40 & 5.0 & 0.64 & 3.70 & 5 \\
\hline $\begin{array}{c}\text { Traffic generators (i.e., Indus. } \\
\text { Residential, business centers etc. }\end{array}$ & 3.50 & 4.0 & 0.70 & 3.90 & 4 \\
\hline $\begin{array}{c}\text { Types of location (e.g., high } \\
\text { (e.g., highways) }\end{array}$ & 3.30 & 5.0 & 0.66 & 4.10 & 7 \\
\hline Focal point of area & 3.80 & 3.0 & 0.78 & 3.50 & $\mathbf{1}$ \\
\hline Retail sales & 3.40 & 10.0 & 0.64 & 3.30 & 6 \\
\hline Eating and drinking sales & 3.60 & 2.0 & 0.72 & 3.80 & 3 \\
\hline
\end{tabular}

Table 5: Factors under General Location in Rank Order of Importance

Source: Field Survey, 2017

Note. MEAN: $1=$ Marginally Influential To 5=Extremely

Influential, Confidence Level: $1=$ Marginally Confident To 5=Extremely Confident

The analysis showed that all factors that were under general location were considered very influential that had means above 3.00. None of the factors had influence below 3.30. This means that all the factors related to with general location are quite influential to site selection.

\begin{tabular}{|c|c|c|c|c|c|}
\hline Factors & Mean & Median & STD.DEV & CV\% & Rank \\
\hline Visibility & 3.40 & 2.5 & 0.90 & 20.0 & 9 \\
\hline Parking & 4.70 & 3.0 & 0.92 & 20.0 & 1 \\
\hline Convenience & 4.30 & 2.0 & 0.86 & 19.11 & 4 \\
\hline Zoning & 3.20 & 3.0 & 0.94 & 20.0 & 10 \\
\hline Signage & 3.50 & 9.0 & 0.82 & 20.0 & 8 \\
\hline Accessibility & 4.50 & 5.0 & 0.70 & 20.0 & 3 \\
\hline $\begin{array}{c}\text { Proximity to industrial, } \\
\text { Residential, business centre etc. }\end{array}$ & 4.10 & 9.0 & 0.64 & 20.0 & 5 \\
\hline Size of site & 3.60 & 5.0 & 0.78 & 20.0 & 7 \\
\hline $\begin{array}{c}\text { Accessibility of utility and } \\
\text { Public services }\end{array}$ & 4.60 & 6.0 & 0.70 & 20.0 & 2 \\
\hline $\begin{array}{c}\text { Type and condition of street (e.g., curbs, } \\
\text { gutters, } \\
\text { Pavements, etc.) }\end{array}$ & 4.00 & 3.0 & 0.84 & 20.5 & 6 \\
\hline
\end{tabular}

Table 6: Factors under Position of Site in Rank Order of Importance Source: Field Survey, 2017

Under position of site five factors were considered very influential, which had means above 4.00 . The factors were, parking (4.70), accessibility of utilities and public services (4.60), accessibility (4.50), convenience (4.30) and proximity to residential, industrial, recreational, sports, educational and business centres (4.10). None of the factors was rated below 3.20 .

\begin{tabular}{|c|c|c|c|c|c|}
\hline Factors & Mean & Median & STD.DEV & CV\% & Rank \\
\hline Residential population & 2.20 & 3.0 & 0.52 & 20.0 & 12 \\
\hline Daytime population & 3.50 & 3.0 & 0.70 & 20.0 & 2 \\
\hline Evening population & 3.40 & 3.0 & 0.52 & 20.0 & 3 \\
\hline Working population & 3.00 & 2.0 & 0.68 & 20.0 & 6 \\
\hline Income & 3.70 & 5.0 & 0.58 & 20.7 & 11 \\
\hline Future growth and Development & 3.40 & 5.0 & 0.68 & 20.0 & 3 \\
\hline Age & 2.60 & 3.0 & 0.78 & 20.08 & 9 \\
\hline Ethnicity & 2.60 & 2.0 & 0.66 & 20.0 & 9 \\
\hline Food preferences & 2.80 & 3.0 & 0.54 & 20.0 & 7 \\
\hline Life style and value & 3.30 & 4.0 & 0.50 & 22.73 & 5 \\
\hline Occupation & 2.70 & 5.0 & 0.40 & 20.0 & 8 \\
\hline Sex & 2.30 & 2.0 & 0.84 & 28.0 & 11 \\
\hline
\end{tabular}

Table 7: Factors under Demographics in Ranking Order of Importance Source: Field Survey, 2017

The analysis showed that, income, daytime population, evening population and future growth and development received higher means that are above 3.40 , other factors had means not below 2.20 respectively. 


\begin{tabular}{|c|c|c|c|c|c|}
\hline Factors & Mean & Median & STD.DEV & CV\% & Rank \\
\hline Traffic counts & 2.40 & 2.0 & 0.6 & 20.0 & 7 \\
\hline Anticipated changes in Traffic flow & 3.00 & 3.0 & 0.52 & 20.0 & 2 \\
\hline Traffic light & 2.10 & 3.0 & 0.50 & 20.0 & 10 \\
\hline Future traffic pattern & 2.50 & 4.0 & 0.50 & 20.0 & 5 \\
\hline Direction of traffic flow & 2.60 & 5.0 & 0.44 & 20.0 & 4 \\
\hline Traffic patterns & 2.40 & 5.0 & 0.56 & 20.0 & 7 \\
\hline Number of lanes & 2.20 & 4.0 & 0.48 & 20.0 & 9 \\
\hline Speed limits & 2.80 & 4.0 & 0.42 & 20.0 & 3 \\
\hline Frequency pattern Of traffic flow & 2.50 & 4.0 & 0.44 & 20.0 & 5 \\
\hline Type of population & 3.20 & 3.0 & 0.56 & 20.0 & 1 \\
\hline
\end{tabular}

Table 8: Factors under Traffic Information in Rank Order of Importance

Source: Field Survey, 2017

The factors that received higher means were types of transportation (3.20), anticipated changes in traffic flow (3.00) and speed limit (2.80). Other factors received means not below 2.10.

\begin{tabular}{|c|c|c|c|c|c|}
\hline Factors & Mean & Median & STD.DEV & CV\% & Rank \\
\hline Location of competitors & 4.00 & 2.00 & 0.82 & 20.50 & 2 \\
\hline Sales volumes of competitors & 3.39 & 4.00 & 0.96 & 28.32 & 6 \\
\hline Quantity of competition & 3.70 & 2.00 & 0.88 & 23.78 & 5 \\
\hline Actual and potential competition & 4.04 & 7.00 & 0.87 & 21.53 & 1 \\
\hline Direct and indirect competition & 3.74 & 7.00 & 0.76 & 20.32 & 4 \\
\hline Quality of competition & 3.91 & 4.00 & 0.83 & 21.23 & 3 \\
\hline Proximity to other Hotels & 3.20 & 2.00 & 0.88 & 27.50 & 7 \\
\hline
\end{tabular}

Table 9: Factors under Competition in Rank Order of Importance

Source: Field Survey, 2017

The highest means under this section are actual and potential competitors (4.04) and location of competitors (4.00) and proximity to other hotels got the lowest mean of 3.20

\begin{tabular}{|c|c|c|c|c|c|}
\hline Factors & Mean & Median & STD.DEV & CV\% & Rank \\
\hline Cost of land & 4.26 & 6.0 & 0.84 & 19.72 & $\mathbf{6}$ \\
\hline Return on investment (ROI) & 4.74 & 8.0 & 0.72 & 15.19 & 2 \\
\hline Cost of construction & 3.34 & 8.0 & 0.92 & 27.54 & 10 \\
\hline $\begin{array}{c}\text { Cost of improvement } \\
\text { (i.e, Renovation and modification) }\end{array}$ & 4.52 & 10.0 & 0.90 & 19.91 & 3 \\
\hline Internal rate of return (IRR) & 4.83 & 8.0 & 0.92 & 19.05 & 1 \\
\hline $\begin{array}{c}\text { Cost of development (i.e, } \\
\text { Purchasing vs leasing) }\end{array}$ & 4.52 & 10.0 & 0.90 & 19.91 & 3 \\
\hline Equipment cost & 4.35 & 2.0 & 0.86 & 19.77 & 5 \\
\hline Labour cost & 4.26 & 3.0 & 0.84 & 19.72 & 6 \\
\hline Property taxes & 3.43 & 4.0 & 0.66 & 19.24 & 9 \\
\hline Utility cost & 3.72 & 2.0 & 0.83 & 19.90 & 8 \\
\hline
\end{tabular}

Table 10: Factors under Cost Consideration in Rank Order of Importance

Source: Field Survey, 2017

The responses under this showed that, internal rate of return ranked first with means (4.83) and return on investment (ROI) ranked second with mean of (4.74). Other factors got means not below 3.30

\section{Findings}

The researcher under six different headings of factors listed a total number of 56 factors. Seven of the factors were related to general location (12.5\%), ten to position of site (17.86\%), and twelve to demographics $(21.42 \%)$, ten to traffic information (17.86\%), seven to competition (12.5\%), and ten to cost of construction (17.86\%). The respondent from all the section ranked internal rate of return (IRR) and return on investment under cost consideration as the highest with means of 4.83 and 4.74 each respectively. The factor that had the lowest mean (2.26) from all the section was working population under demographics. All the factors related to general location, position of site, completion, and cost consideration received means not below 3.0. The proposition here is, the factors under general location position of site and cost consideration are the major concerns that influence the location choice of hotel property in the study area. The results indicated strong support for this proposition. There were seven factors under general location, ten under position of site, seven under competition, and ten under cost consideration. According to the data gotten from the questionnaires administered to the professionals, all of the factors related with general area, position of site, competition, and cost 
consideration received means above 3.00, which mean that they are quite influential in making decision related to location choice. This information shows that the factors under general location, position of site, competition, and cost consideration are major aspects that influence the location choice of the hotel properties in the study area.

\section{Conclusion}

The respondents reached a consensus on the location choice factors on most of the issues except all the factors under traffic information but one received mean of (3.09), and six factors under demographics. These factors were age, ethnicity, occupation, residential population, sex, working population, direction of traffic flow, and frequency pattern of traffic flow, future traffic pattern, number of lanes, traffic accounts, traffic lights, and traffic pattern, respectively. This means that the respondents did not agree on the importance or influence level of these thirteen issues. All the factors under general area, position of site and cost consideration were agreed as being the quite influential according to the means obtained from the responses of the respondents. In addition, the respondents had agreed on the importance or influence level of these factors. However, this does not mean that the professionals should overlook other factors related with demographics and traffic information that received a mean above 3.00 by this study. The nature of this research is practical because experienced professionals developed the location choice factors. This study identified 56 factors that affect hotel in the study area. Those hotel professionals who plan to expand but have little experience with the real estate development should examine all of these.

\section{Limitations}

As with the general nature of any research, there are a number, limitations associated with this study. One of the limitations of this study is that the size of the respondent groups was relatively small, so that it would be difficult to generalize some of the study's results. The respondents of the study were selected from hotel managers and practicing Estate Surveyors and Valuers residing in the study area. This restricts the total sample to 30 . Therefore, the results of this study depend heavily on the expertise of the participating professionals. In addition, the location choice factors were indentified without measuring the performance of the hotel property. The ultimate test of strength for any hotel system is how each individual unit performs and the ultimate measure of success is the return on investment generated by each hotel property. Further study may focus on linking financial analysis to location choice.

\section{Recommendations}

Lack of attention to potentially influencing factors may lead to an unsuccessful operation. The following recommendations are made for utilization of the results of this study for choosing location for hotel properties Factors identified through this study should be used as guidelines for hotel companies when planning to build or expand their units. Each factor should be considered regarding its influence level on final choice. The location choice factors identified as being quite influential should be examined closely from their analysis. Major factors identified should be given more attention while making location choice decision.

\section{References}

i. Alañón-Pardo, Á., \& Arauzo-Carod, J. M. (2013). Agglomeration, accessibility and industrial location: Evidence from Spain. Entrepreneurship and Regional Development, 25(3-4), 135-173.

ii. Ali, S. M., El-barmelgy, M. M., Shalaby, A. M., Nassar, U. A., \& Ali, S. M. (2014). Economic Land Use Theory and Land Value in Economic Land Use Theory and Land Value in Value Model, (January).

iii. Ansar, A. (2013). Location decisions of large firms: Analyzing the procurement of infrastructure services. Journal of Economic Geography, 13(5), 823-844.

iv. Aw, B. Y., \& Lee, Y. (2014). A model of demand, productivity and foreign location decision among Taiwanese firms. Journal of International Economics, 92(2), 304-316.

v. Belkhodja, O. (2016). FDI Location Decision: Evidence from Firms Investing in China. International Journal of Business and Management, 11(6), 47.

vi. Cliquet, G. (2013). Retail Location Models. In Geomarketing: Methods and Strategies in Spatial Marketing (pp. 137-164).

vii. Corgel, J. B., Liu, C., \& White, R. M. (2015). Determinants of Hotel Property Prices. Journal of Real Estate Finance and Economics, 51(3), 415-439.

viii. Dong, H. (2013). Concentration or dispersion Location choice of commercial developers in the Portland Metropolitan Area, 2000-2007. Urban Geography, 34(7), 989-1010.

ix. Dubé, J., Brunelle, C., \& Legros, D. (2016). Location Theories and Business Location Decision : A Micro-Spatial Investigation of a Non-Metropolitan Area in Canada*. The Review of Regional Studies, 46(2), 143-170.

x. Eckert, A., He, Z, \& West, D. S. (2015). An empirical analysis of tenant location patterns near department stores in planned regional shopping centers. Journal of Retailing and Consumer Services, 22.

xi. Elgar, I., Farooq, B., \& Miller, E. J. (2015). Simulations of firm location decisions: Replicating office location choices in the Greater Toronto Area. Journal of Choice Modelling, 17, 39-51.

xii. ELSamen, A. A. A., \& Hiyasat, R. I. (2017). Beyond the random location of shopping malls: A GIS perspective in Amman, Jordan. Journal of Retailing and Consumer Services.

xiii. Freeman, J., \& Styles, C. (2014). Does location matter to export performance? International Marketing Review, $31(2), 181-208$. 
xiv. Giner, J. M., Santa-María, M. J., \& Fuster, A. (2017). High-growth firms: does location matter? International Entrepreneurship and Management Journal, 13(1), 75-96.

xv. Guzman, L. (2015). Localization Factors from Japanese Firms in Automotive-related Industries in Mexico. Procedia Economics and Finance, 30, 265-270.

xvi. He, X, \& Wei, Y. (2013). Export market location decision and performanceThe role of external networks and absorptive capacity. International Marketing Review, 30(6), 559.

xvii. He, Z., Cheng, T. C. E., Dong, J., \& Wang, S. (2016). Evolutionary location and pricing strategies for service merchants in competitive O2O markets. European Journal of Operational Research, 254(2), 595-609.

xviii. Hou, Y. (2016). Traffic Congestion, Polycentricity, and Intraurban Firm Location Choices: a NestedL Logit Model for the Los Angeles Metropolitan area.Journal of Regional Science, 56(4), 683-716.

xix. Ishikawa, T. (2015). Firms' location selections and regional policy in the global economy. Firms' Location Selections and Regional Policy in the Global Economy.

xx. Johnson, R. B., and Onwuegbuzie, A. J. (2004) "Mixed Methods Research: A Research Paradigm Whose Time Has Come." Educational Researcher 33, (7) 14-26

xxi. Karakitsiou, A. (2015). Modeling discrete competitive facility location. Modeling Discrete Competitive Facility Location.

xxii. Kimelberg, S. M., \& Williams, E. (2013). Evaluating the Importance of Business Location Factors: The Influence of Facility Type. Growth and Change, 44(1), 92-117.

xxiii. Lee, B. (2013). Assessing the maturity of central place using focal location quotients. Journal of the Korean Society of Surveying Geodesy Photogrammetry and Cartography, 31(3), 221-228.

xxiv. Li, G., Chen, S., Feng, J., Tan, K, \& Li, W. (2014). Efficient Location-Aware Influence Maximization. In Proceedings of the 2014 ACM SIGMOD international conference on Management of data (pp. 87-98). Johnson, R. B., and Onwuegbuzie, A. J. (2004) "Mixed Methods Research: A Research Paradigm Whose Time Has Come." Educational Researcher 33, (7) 14-26

xxv. Li, Y. M., Chou, C. L., \& Lin, L. F. (2014). A social recommender mechanism for location-based group commerce. Information Sciences, 274, 125-142.

xxvi. Lv, P., \& Spigarelli, F. (2016). The determinants of location choice. International Journal of Emerging Markets.

xxvii. Mahmutogullari, A. I., \& Kara, B. Y. (2016). Hub location under competition. European Journal of Operational Research, 250(1), 214-225.

xxviii. Melanda, E., Hunter, A., \& Barry, M. (2016). Identification of locational influence on real property values using data mining methods. CyberGeo,

xxix. Mesquita, L. F. (2016). Location and the Global Advantage of Firms. Global Strategy Journal, 6(1), 3-12.

xxx. Mulley, C., Ma, L., Clifton, G., Yen, B., \& Burke, M. (2016). Residential property value impacts of proximity to transport infrastructure: An investigation of bus rapid transit and heavy rail networks in Brisbane, Australia. Journal of Transport Geography, 54, 41-52.

xxxi. Mulley, C., \& Tsai, C. H. Patrick. (2016). When and how much does new transport infrastructure add to property values? Evidence from the bus rapid transit system in Sydney, Australia. Transport Policy.

xxxii. Newing, A., Clarke, G. P., \& Clarke, M. (2014). Developing and Applying a Disaggregated Retail Location Model with Extended Retail Demand Estimations. Geographical Analysis.

xxxiii. North, J., \& Miller, F. L. (2017). Facility location using GIS enriched demographic and lifestyle data for a traveling entertainment troupe in Bavaria, Germany. Decision Support Systems.

xxxiv. Nzilani, M. J. (2014). An Investigation into the Impact of increased Development of Shopping malls on the Kenyan, (May).

xxxv. Ongore, V. O., \& Kusa, G. B. (2013). Determinants of Financial Performance of Commercial Banks in Kenya. International Journal of Economics and Financial Issues, 3(1), 237-252.

xxxvi. Ozuduru, B. H., \& Guldmann, J. (2013). Retail location and urban resilience: towards a new framework for retail policy. S.a.P.I.E.N.S., 6(1), 1993-3800.

xxxvii. Pick, J. B., Turetken, O., Deokar, A. V., \& Sarkar, A. (2017). Location analytics and decision support: Reflections on recent advancements, a research framework, and the path ahead. Decision Support Systems.

xxxviii. Quintos, C. (2013). Spatial Weight Matrices and Their Use As Baseline Values and Location-Adjustment Factors in Property Assessment Models. Cityscape: A Journal of Policy Development and Research, 15(3), 295-306.

xxxix. Rajkumar, P. (2013). A study of the factors influencing the location selection decisions of information technology firms. Asian Academy of Management Journal, 18(1), 35-54.

xl. Robinson, L., \& Stocken, P. (2013). Location of Decision-rights within Multinational Firms. Journal of Accounting and Economics, (July), 1-57.

xli. Russell, J. E. (2013). Using a Retail Location Game to Explore Hotelling's Principle of Minimum Differentiation. Business Education Innovation Journal, 5(2), 48-52.

xlii. Shao, Y., \& Shang, Y. (2016). Decisions of OFDI Engagement and Location for Heterogeneous Multinational firms: Evidence from Chinese firms. Technological Forecasting and Social Change, 112, 178-187.

xliii. Tate, W. L., Ellram, L. M., Schoenherr, T., \& Petersen, K. J. (2014). Global competitive conditions driving the manufacturing location decision. Business Horizons, 57(3), 381-390.

xliv. van den Heuvel, F., van Donselaar, K., de Langen, P., \& Fransoo, J. (2016). Co-Location Synergies: Specialised Versus Diverse Logistics Concentration Areas. Tijdschrift Voor Economische En Sociale Geografie, 107(3), 331346. 
xlv. Verhetsel, A., Kessels, R., Goos, P., Zijlstra, T., Blomme, N., \& Cant, J. (2015). Location of logistics companies: A stated preference study to disentangle the impact of accessibility. Journal of Transport Geography.

xlvi. Xu, T., Zhang, M., \& Aditjandra, P. T. P. (2016). The impact of urban rail transit on commercial property value: New evidence from Wuhan, China. Transportation Research Part A, 91(91), 223-235.

xlvii. Yang, Y., Luo, H., \& Law, R. (2014). Theoretical, empirical, and operational models in hotel location research. International Journal of Hospitality Management, 36, 209-220.

xlviii. Yang, Y., Tang, J., Luo, H., \& Law, R. (2015). Hotel location evaluation: A combination of machine learning tools and web GIS. International Journal of Hospitality Management.

xlix. Zhao, J., Lasternas, B., Lam, K. P., Yun, R., \& Loftness, V. (2014). Occupant behavior and schedule modeling for building energy simulation through office appliance power consumption data mining. Energy and Buildings, 82, 341-355.

1. Zhuge, C., Shao, C., Gao, J., Dong, C., \& Zhang, H. (2016). Agent-based joint model of residential location choice and real estate price for land use and transport model. Computers, Environment and Urban Systems, 57. 